\title{
Transformation of the Social Insurance Management Agency on Health
}

\author{
Endang Sulistyaningsih ${ }^{1}$, Hartiwiningsih ${ }^{2}$, Is Haryanto ${ }^{2}$ \\ ${ }^{1}$ Doctoral Student at Legal Studies, Sebelas Maret University, Surakarta, Indonesia, \\ ${ }^{2}$ Lecturer at Sebelas Maret University, Surakarta, Indonesia
}

\begin{abstract}
Health insurance is a type of insurance product that specifically guarantees the cost of health or care of the insurance members if they are sick or have an accident. Implementation of social security is a state obligation mandated by the 1945 Constitution. The issuance of the Social Insurance Management Agency (BPJS) act as the implementer of the National Social Security System act (SJSN) resulted in PT Askes transforming into Social Insurance Management Agency on Health (BPJS Kesehatan). The National Social Security System is organized on the basis of humanitarian principles, principles of benefit, and the principle of social justice for all Indonesians. The National Social Security System aims to provide and guarantees the fulfillment of a decent life base for each participant and/or his family member. The National Social Security System is organized on the basis of such principles: mutual cooperation, non-profit, disclosure, prudence, accountability, portability, mandatory membership, trust fund, and the social security fund will be used entirely for program development and for the interest of participants. Although the preparation and implementation of the National Social Security System is quite well, but in reality there are still various impacts and problems encountered in the operation of BPJS Kesehatan such as lack of socialization, service facilities, inappropriate data, and personnel who are still lacking in giving a good services and information.
\end{abstract}

Keywords: Health insurance, legal analysis, transformation, BPJS Kesehatan.

\section{Introduction}

Health insurance is a type of insurance product that specifically guarantees the cost of health or care of the insurance members if they are sick or have an accident. Health insurance is a type of insurance product that specifically guarantees the cost of health or care of insurance members if they fall ill or have an accident. Health insurance products are usually provided by social insurance companies, life insurance companies, and general insurance companies. In Indonesia, PT Askes Indonesia is one of the social insurance companies that

\section{Corresponding Author:}

\section{Endang Sulistyaningsih}

Sebelas Maret University, Jl. Ir. Sutami No. 36, Jebres, Surakarta, Central Java 57126, Indonesia organize health insurance for its members in need both for civil servants and non-civil servants. Their children will also be financed until the age of 21 st. It also applies to pensioners.

PT Askes (Persero) is a State-Owned Enterprise specially assigned by the government to provide health care insurance for Government Civil Servants, TNI (Indonesian National Army), POLRI (Indonesian National Police), pensioners, veterans, families of the pioneers of Indonesian independence and other Business Entities. Health Insurance Program (ASKES) which is organized under Government Regulation No. 69 of 1991 is mandatory for civil servants/recipients of pensions/ pioneers of independence/veterans and members of their families.

Over the last few decades, Indonesia has implemented several social security programs. The law that specifically regulates social security for private 
workers is Law No. 3 of 1992 on Social Security of Workers (JAMSOSTEK) which includes health care insurance program, accident insurance, old-age insurance and death insurance. For Civil Servants (PNS), there are savings fund program and Insurance of Civil Servants (TASPEN) which were established under Government Regulation No. 26 of 1981. Besides that, there is also Health Insurance Program (ASKES) which is based on Government Regulation No. 69 of 1991.

For Indonesian National Army (TNI), members of the Indonesian National Police (POLRI), civil servants of the Department of Defense/TNI/POLRI and their families, the Indonesian Armed Forces Social Insurance (ASABRI) program has been implemented in accordance with Government Regulation No. 67 of 1991 which is a change from Government Regulation No. 44 Year 1971.

Programs mentioned above cover only a small percentage of Indonesian, while the majority of them have not received adequate protection. In addition, the implementation of various social security programs has not been able to provide fair and sufficient protection to the participants in accordance with the benefits of the program which are the rights of participants. In relation to the above, it is deemed necessary to develop a social security system capable of synchronizing the various forms of social security implemented by some organizers in order to reach wider membership and provide greater benefits for each participant.

Act 4 of the BPJS Law (No. 24 of 2011) contains BPJS principles such as mutual cooperation, nonprofit, disclosure, prudence, accountability, portability, mandatory membership, trust fund, and the social security fund will be used entirely for program development and for the interest of participants.

The non-profit principle in BPJS is different from the goal of the establishment of state-owned enterprises, which is to pursue profits to improve the company. The principles set forth in the BPJS law will change many things in the implementation of social security in Indonesia. The preparation period of the transformation from PT ASKES (Persero) to BPJS Kesehatan was starting from November 25, 2011 to January 1, 2013. It has started on January 1, 2014 and also explained the purpose of the transformation is to make it easier and improve health insurance services to the public. One of the principles of BPJS Health is the principle of mutual cooperation which means to help each other so that the social security system is in accordance with the basic philosophy of 5th principle of Pancasila (Social Justice for all Indonesian people). The focus of this paper will discuss the implementation of Article 57 of the BPJS Law concerning the transformation of PT ASKES (Persero) into the BPJS Kesehatan and the juridical implications of its' transformation.

Utilitarianism, Theory of Law and Social Change: The theory of utilitarianism was conceived to state that the law is made to benefit the society and the law should be based on benefits for human happiness. ${ }^{1,2}$ So, this understanding assesses whether it is good or not in terms of usefulness or benefits that it comes. The basic principle of utilitarianism is a moral act or regulation that can support the happiness of all concerned so that it can benefit all citizens.

The development of material law and procedural law follow certain stages, ranging from simple form to the most advanced stage in which law is organized systematically. ${ }^{3}$ He states that the changes of the law are in accordance with the changes that occur in the social system of society that supports the legal system.

The law is said to be a tool for changing society, as it is known that the law was born by man and to guarantee the interests and rights of man himself. From this man the color of law and its application will determine what he will experience in the association of his life. ${ }^{4}$ Law is a tool to change society. It means that the law is used as a tool by the agent of change or a pioneer of change (a person or group of people who gain the trust of the community as the leader of the community institutions).A planned social change is always under control of the pioneer of the change. Therefore, if the government wants to establish bodies that have function to change society, then the law is required to establish the body to determine and limit its power. ${ }^{5}$

Health Insurance Management on National Constitution: Pancasila and the 1945 Constitution mandated that the state has a responsibility to protect the entire Indonesian and promote the general welfare in the context of realizing social justice for all Indonesian people. It is to realize a decent and dignified life and to fulfill the right to the basic needs of the citizens for the achievement of social welfare, the State organizes the service and development of social welfare in a planned, directed and sustainable manner. State and social security are components that integrate with social protection 
systems. National social security systems include health insurance, life insurance, accident insurance and pension benefits financed by employer contributions and employee contributions. The National Social Security System (SJSN) is a lifelong social program that forms a social protection system composed of parts of the approach system in the provision of social security and as an effort to create jobs by the government and empowerment of the marginal community to become a prosperous self-reliant community. ${ }^{6}$ The National Social Security System which is based on Law No. 40 of 2004 (about the National Social Security System/SJSN) is a state program for a lifetime that must be held by a public legal entity with permanent legal force.To answer the problem of juridical study of the transformation of PT Askes (Persero) into BPJS Kesehatan, the writer uses Utilitarianisme Theory and Social Change Theory.

Implementation of Article 57 BPJS Law on Transformation of PT Askes (Persero) into BPJS Kesehatan: The definition of policy implementation according to Van Metten and Van Horn is acts committed by individuals, officials, government, or private groups directed to achieve the objectives outlined in policy decisions. $^{7}$

As it is known that PT Askes (Persero) is a StateOwned Enterprise (BUMN) that organizes a social security program, its capital is partly or wholly owned by the government. There are 3 kinds of BUMN. First, Perjan is a BUMN whose capital is owned by the government. Perjan is service-oriented towards the community. Second, Perum is a Business Entity managed by State whose purpose is to gain profit and provide services to the public. Third, Persero is one of the Business Entities managed by State or Region. Unlike Perum or Perjan, the main purpose of establishing a Persero is to seek profit (commercial).

At the beginning, the form of business entity of PT Askes (Persero) was in the form of a public company (Perum) under the name of Perum Husada Bhakti and based on Government Regulation No. 6 of 1992, the status of Perum was changed to a company (PT) and then on January 1, 2014 PT Askes (Persero) changed its name to BPJS Kesehatan based on Law Number 24 of 2011 on BPJS.

Characteristics of BPJS Kesehatan that different from other BUMNs is to pursue profit in order to increase the value of the company. BPJS Kesehatan is oriented to serve community. It has a non-profit principle, the management of trust funds by BPJS Kesehatan is not for profit (for profit oriented) but to meet the maximum interests of participants. Funds collected from participating are trust funds which is managed for the welfare of the participants. So the results of its development will be utilized as much as possible for the benefit of participants.

As a private legal entity, a Persero Company is not established by a state authority with a law but established by an individual, as any other public company should be registered with a Notary and authorized by the Ministry of Justice and Human Rights.

In contrast, the establishment of the Social Insurance Management Agency (BPJS) by state authorities is established under National Social Security System Act and Social Insurance Management Agency Act. The establishment of BPJS is not registered with a notary public and does not require the authorization of a government agency.

The main obstacle encountered by BUMN Persero is the ineffectiveness of social security law enforcement because there is no authority to regulate, supervise or impose sanctions on participants. On the contrary, the BPJS as a public legal entity has the power and authority to govern the public through the authority to make public binding regulations. As a public legal entity, BPJS is obligated to convey responsibility for the performance of its duties to the President. BPJS deliver its performance in the form of annual program management and financial report audited by a public accountant to the President with carbon copy to the National Social Security Board, no later than June 30th of the following year.

In 2004 the government established and enacted Law Number 40 of 2004 on National Security System as the implementation of Article 5 paragraph (1) and Article 52 of the National Social Security System Law after the Constitutional Court's decision No. 007/PUU-III/2005 dated 25 November 2011 and enacted Law Number 24/2011 on the Social Insurance Management Agency. BPJS Kesehatan starts to operate on January 1st, 2014 and PT Askes (Persero) was closed without liquidation. At the same time, the Minister of BUMN through the General Meeting of Shareholders approved the report on closing financial position of PT Askes (Persero) after the audit at the public accounting firm and the Minister of Finance authorized the opening financial position of 
BPJS Kesehatan and the opening social security fund report. For the first time, the Board of Commissioners and the Board of Directors of PT Askes (Persero) was appointed as BPJS Kesehatan Supervisory Board for a maximum period of 2 years since BPJS Kesehatan started to operate.

The final change from the transformation processes of BPJS is the change of organizational culture. ${ }^{6}$ In Article 40 paragraph (2) of BPJS Law, it requires BPJS to separate the assets of BPJS and the assets of the Social Security Fund. Article 40 paragraph (3) of the BPJS Law affirms that the assets of the Social Security Fund are not an asset of BPJS. This assertion ensures that the Social Security Fund is a trust fund of all participants and not the assets of BPJS.

Furthermore, in Article 4 of BPJS Law, it regulates BPJS principles: principles of mutual cooperation, nonprofit principles, principles of openness, prudential principles, accountability principles, portability principles, compulsory membership principles and trust fund principles.

Juridical Implications of the Transformation of PT Askes (Persero) into BPJS Kesehatan: The legal basis for the transformation of PT Askes (Persero) into BPJS includes Law Number 40 of 2004 regarding National Social Security System and Law Number 24 of 2011 on BPJS.Furthermore, some Government Regulations (PP) and Presidential Regulations (Perpres) also regulate the implementation of BPJS Kesehatan. From the various legal basis underlying the transformation of PT Askes (Persero) into BPJS whether it is based on the Law, Government Regulation, or Presidential Regulation, there are various impacts or consequences of it. For the company, the impact is that the company must register its employees to BPJS Kesehatan. Furthermore, company are required to allocate funds to pay contributions to BPJS Kesehatan. For society, the impact is that membership is mandatory and participants must pay the contribution.

Factors that impede the implementation of the National Health Insurance currently encountered by BPJS Kesehatan are some, including (1) lack of socialization; (2) inadequate number of health service facilities and uneven distribution, especially for remote areas, borders and islands with low service levels due to geographical conditions and poor health facilities in the area; (3) lack of treatment room facilities resulting in many patients experiencing delay in handling because they have to wait for an empty treatment room to be served (especially at government hospitals); (4) the number of health personnel is less than the required amount; (5) the problem will arise in the contribution participants (PBI) because the data is not in accordance with conditions in the field so this causes serious problems.

\section{Conclusion}

Based on Government Regulation No. 6 of 1992 the status of Perum is changed to a Persero company and from January 1, 2014, PT Askes changed its name to BPJS Kesehatan based on Law no. 24 of 2011. At that time PT Askes (Persero) was closed without liquidation and also accompanied by the transfer of assets, rights and obligations of PT Askes (Persero) and its employees moved into BPJS Kesehatan. Characteristics of BPJS are oriented to serve community. Funds collected from participants' contribution are trust funds that will be managed for the welfare of participants. The juridical implications of PT Askes (Persero) transformation into BPJS Kesehatan is affecting the company where it is required to register its employees to BPJS Kesehatan and the company must allocate funds to pay the contribution of BPJS Kesehatan. Impact for participants or communities is participants must pay contributions to BPJS Kesehatan except for whose premium paid by the government.

Ethical Clearance: This research was ethically approved by Sebelas Maret University.

Funding: This research receives no external funding.

Conflict of Interests: There are no conflict of interests

\section{References}

1. Bentham J, Mill JS. The utilitarians. Garden City, NY: Anchor Press/Doubleday;1973.

2. Tanya BL, Simanjuntak YN, Hage MY. Teori Hukum Strategi Tertib Manusia Lintas Ruang dan Generasi. Genta Publishing;2010.

3. Weber M. From Max Weber: Essays in sociology. Routledge;2009.

4. Dirdjosisworo S. Sosiologi Hukum. Rajawali Pers; 1983. 
5. Soemardjan S. Sifat-sifat panutan di Dalam Pandangan Masyarakat Indonesia. Masalahmasalah Ekonomi dan factor-faktor Ipolsos, Leknas, Mipi, Rajawali Press; 1965.

6. Sulastomo. Sistem Jaminan Sosial Nasional Sebuah Introduksi. Rajawali Press;2008.
7. El Kawaqi. http//:www.el kawaqi.blogspot.com, Artikel Implementasi Menurut Para Ahli, 2012, accessed January 15, 2018. 